\title{
Erratum to: Bartonella spp. - a chance to establish One Health concepts in veterinary and human medicine
}

Yvonne Regier, Fiona O'Rourke and Volkhard A. J. Kempf

\section{Erratum}

Unfortunately, the original version of this article [1] contained an error. The name of the author Fiona O'Rourke was incorrectly spelt as Fiona O'Rourke. The correct spelling is included here, and has been updated in the original article.

Received: 25 May 2016 Accepted: 25 May 2016

Published online: 10 June 2016

\section{References}

1. Regier Y, O'Rourke F, Kempf VAJ. Bartonella spp. - a chance to establish One Health concepts in veterinary and human medicine. Parasit Vectors. 2016; 9:261. doi:10.1186/s13071-016-1546-x.

Submit your next manuscript to BioMed Central and we will help you at every step:

- We accept pre-submission inquiries

- Our selector tool helps you to find the most relevant journal

- We provide round the clock customer support

- Convenient online submission

- Thorough peer review

- Inclusion in PubMed and all major indexing services

- Maximum visibility for your research

Submit your manuscript at www.biomedcentral.com/submit

\section{() Biomed Central}

